Jusmal lemiah
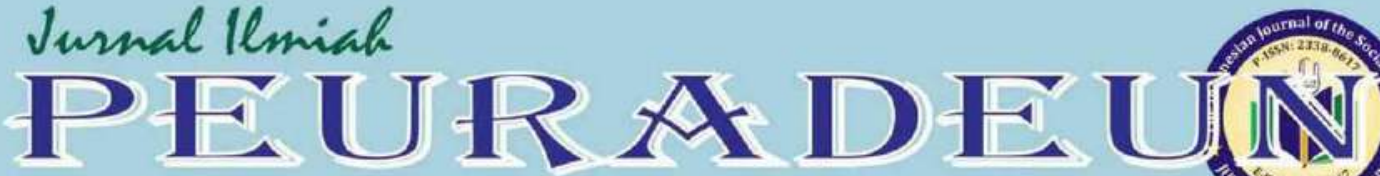

Vol. 6, No. 1, January 2018

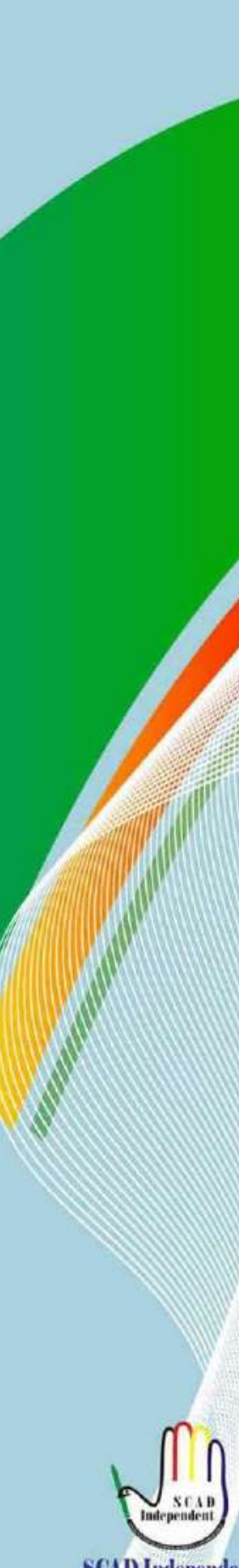

SCAI) Independent Accreditatioa by HO since 2014 $\bigodot$ Copernicus Publications

\section{III}

The Indonesian Journal of the Social Sciences www.journal.scadindependent.org Dot Prefix Number: 10.26811

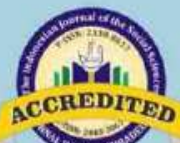

ACCREDITED - B" by the Ministry of Risteklikti from Oetaber 30, 2017 until Oetober 30, 2022

\section{Clarivate Analytics}

Emerging Sources Citation Index Web of Science ${ }^{\mathrm{TM}}$

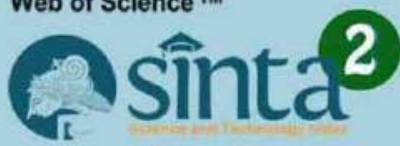
INDEX $\circledast$ COPERNICUS 


\title{
ISLAMIC EDUCATION WITH NATIONAL INSIGHT VIEWED FROM ISLAMIC PERSPECTIVE
}

\author{
Sulthan Syahrir \\ Raden Intan State Islamic University Lampung, Indonesia \\ Contibutor Email: sultansyahrir@radenintan.ac.id
}

Received: Oct 17, 2017

Accepted: Dec 28, 2017

Published: Jan 28, 2018

Article Url: http://journal.scadindependent.org/index.php/jipeuradeun/article/view/192

\begin{abstract}
There are three profound principles covered in this research including the Islamic view of national insight, the Islamic view of Islamic education with national insight and the implementation of Islamic education with national insight in the Republic of Indonesia. This research was intended to observe, identify and describe those issues. As the primary data were gathered by analyzing the various related literatures written by the experts of Islamic education as well as constitutional law, this research falls into the category of library research. Descriptive and analytical methods were simultaneously employed in carrying out this research. The former was to provide a general description of the issue to be interpreted, while the latter was to scrutinize the background of the issue. Data were then analyzed using content analysis technique. The finding of the research reveals that the proper model of Islamic education with national insight is the one with multi ethnicity and plurality of religion and culture for the sake of the unified Republic of Indonesia, a prosperous and blessed country.
\end{abstract}

Keywords: Islamic Education, National Insight, Qur'an, Sunnah 


\section{A. Introduction}

This research is trying to address three fundamental mental problems: 1) How does Islam view national insight?; 2) How does Islam observe Islamic education with national insight?; and 3) How is the implementation of Islamic education with national insight in the Republic of Indonesia? The actualization of Islamic education with national insight ${ }^{1}$ means the education which drives the Indonesian nation with its multi-ethnic groups and plurality of religion and culture to keep the unity of Republic of Indonesia.

In addition, Islamic education with national insight (sense of nationalism) was not recognized in the era of Qur'an revelation, but it emerged and widespread in Europe in the $18^{\text {th }}$ century and finally reaching the Islamic world. This concept of education is very ideal for the context of education in Indonesia to create a unified and harmonious country since it is the homeland of various ethnic groups, religions and cultures. It is in line with the values of Pancasila and 1945 Constitution which substantially are not against the Qur'an and Sunnah (prophetic traditions) as the basis of Islamic education having been utilized by the Islamic scholars for a long time.

The issue of education ${ }^{2}$ with nation insight in Islam is apparently an actual discourse in Indonesia. Quality education will undoubtedly enhance the quality of human resources to be more civilized individuals upholding the moral values in their social life. Unfortunately, although

\footnotetext{
${ }^{1}$ National insight was initially introduced to Muslims by Napoleon Bonaparte during the expedition to Egypt, after French Revolution in 1789. Egypt was once under the rule of the Mamluks and Ottoman Empire.In his decree, Napoleon introduced the new term al-Ummat alMishriyah to go along with the old one al-Ummah al-Islamiyah. Al-Ummah al-Mishriyah means Egyptian nation. As such, more nations were emerging. (Wawasan Kebangsaan Islam dan Pancasila- Seientific Article, p. 1. Accessed on Saturday, January, 14, 2017).

${ }^{2}$ Education is basically a pedagogical effort to transfer the social norms and values to certain pupils through the process of learning. The way of life of a nation which reflects the adopted virtues is formulated into constitution and laws. The philosophical belief of the nation is included therein for instance the implemented educational system. In Indonesia, for example, the philosophical view of edu-cation is overtly stated as the national objective in the Preamble of 1945 Constitution the $4^{\text {th }}$ paragraph. In general, the objective of national education is to foster the intellectual life of the nation. It is further elaborated in the Constitution Number 202003 about System of National Education. (Pendidikan dalam Pandangan Islam- Scientific Article, p. 5. Accessed on Monday, 16 January 2017.).
} 
many educational institutions have already had good facilities and well accredited, they fail to produce civilized human beings. This may happen due to the absence of vision and commitment to the improvement of civilization through education (Hitami, 2004: 25). Meanwhile, Islamic education is always in relation to social life because essentially, education holds the most important role for human beings to augment their faith to Allah the Almighty. Besides, the better someone understands of Islamic education principles is, the closer relation to Allah the Almighty he/she will have (Syalabi, 1945: 21).

Therefore, Indonesia has to keep growing as an Islamic moralitybased nation to make it powerful and prosperous. The main problem is Indonesia is likely to be a soft state where the concept of right or wrong is quite absurd. Nurcholish Madjid (1998: 20) asserts that most Muslims in Indonesia practice the religion based on the formalistic and symbolic characteristics affected by the historical-sociological aspects. As a result, symbols seem to be more urgent than the essence, for instance the presence of Islamic State or Islamic Law. On the contrary, the virtues of Islamic teachings are often neglected. The true essence of Islamic values have already been adopted in Pancasila (the Five Pillars) and 1945 Constitution. It merely needs creativity and innovation of Islamic scholars to actualize the virtues in the daily lives of Indonesian people as a nation by promoting harmony, unity and prosperity of the nation.

Islamic education with national insight in the perspective of Islam deems the substance of education ${ }^{3}$ as the process to prepare human beings to acquire the capability to bear the responsibility of being the caliph of Allah on earth. For this purpose, human beings are equipped with the

\footnotetext{
${ }^{3}$ Based on Islamic teaching, education is aimed at preparing human beings to carry out their duty both as servant and caliph of Allah, that is the ones who are aware of their position as the creatures who must obey the orders of the creator. Accordingly, through education the necessitated knowledge, under-standing as well as skills are provided to optimally make good use of the universe. For this purpose, there should be definite stages and specifications of education offered by the management of educational institutions. (Fauziyatul Halim, et.al., Pandangan Pendidikan dalam Ditinjau dari perspektif Islam, Scientific Magazine, p. 9. Under supervision of Dr. Imam Jauhari, SH., M. Hum. Science of Law Post-Graduate Program of Syiah Kuala University Darussalam Banda Aceh, 2014. Accessed on Saturday, January, 14, 2017).
} 
potency of learning through their mind. Basically Allah the Almighty sent His Messengers to all human beings in order to guide them to civilized creatures through His books and education (QS. al-Baqarah: 129). The instruction of reading is the firstly revealed Qur'anic verse which emphasizes the importance of educational process for human beings (QS. al-'Alaq: 1-5). The Prophetic traditions also highlight the importance of education. Factually, the existence of Islam has uplifted the civilization of Arab people through education. Prophet Muhammad historically treated the hostages of Badar war very kindly and requested the literate ones to teach reading and writing to children in Medina in return for their release. Prophet Muhammad also encouraged his followers to keep carrying out lifelong learning.

Also, there are some previous research with similar interest as the supporting argumentation of this study. The first one is Sigit Sumarhaen Yanto (2009) writing about "Education with National Insight" with the conclusion that there has been degradation of national insight nowadays due to the impact of massive development of the strategic circumstances. It is indicated by the immense expose of such crimes as the drug abuse, corruption, collusion and nepotism and many more in mass media. Thus, it is necessary to revitalize the concept and imple-mentation of national insight education by upholding the virtues of Indonesian people referring to Pancasila to avoid the negative impacts of globalization. It surely demands the synergic work of family, society and educational institutions as well.

In addition, Yatdi (2013) conducted a research about "The Concept of Education with National Insight (A Comparative Study on the Notion of Ki Hajar Dewantara and Muhammad 'Athiyah al-Abrasyi)" concluding that there are some similarities as well as differences between the two. Some of the similarities include the national insight education should be based on humanity, freedom and democracy. Besides, they also share similar ideas on the conceptual objectives, namely by instilling the patriotism, independence, nationalism, unity, harmony, democracy, manner, faith and devotion to Allah 
the Almighty. About the learning materials, they agreed on the importance of language, religion, arts, music, poetry and physical education. On the other hand, the major difference between the two is about the fundamental concept of education. While Ki Hajar Dewantara emphasized on the immense cultural values in terms of the learning materials and learning process which should be in accordance to the cultural life of the nation, Muhammad 'Athiyah AlAbrasyi paid more attention to Islamic education soul including manner education by providing the good examples to pupils and the use of Arabic language as the medium of instruction.

Further, Aida (2013) expressed her ideas about "Developing the nation through National Insight Education. She summed up that seeing the condition of national insight of Indonesian people nowadays if not positively responded immediately may cause the following impacts: (1) the failure to properly understand the virtues of Pancasila, especially regarding national insight; (2) the absence of sense of nationalism as strongly asserted by Pancasila; and (3) the spirit of nationalism will fade away. This may occur as the result of insufficient understanding of the virtues of Pancasila, not to mention to actualize and internalize those virtues.

\section{B. Research Method}

This study belongs to library research by analyzing various related literatures, particularly about Islamic education with national insight viewed from Islamic perspective written by the experts of Islamic education and constitutional law. Descriptive and analytical methods were simultaneously employed in carrying out this research. The former was to provide a general description of the issue to be interpreted, while the latter was to scrutinize the background of the issue. Data were then analyzed using content analysis technique. The data intended of Islamic Education with National Insight Viewed From Islamic Perspective, the consists of Islamic Educational Concept and National Insight Viewed from Islamic Perspective. 


\section{Research Findings and Discussion}

In data analysis there are two fundamental points to be scrutinizedconcept of Islamic education and national insight viewed from Islamic perspective. The concept of Islamic educa-tion covers such details as the understanding, the objective, the foundation and source and the scope of Islamic education. The second point, national inside viewed from Islamic perspective, highlights the description of the understanding, the nature, and the Islamic perspective of national insight.

\section{Concept of Islamic Education}

\section{a. The Understanding of Islamic Education}

Literally, Islamic education ${ }^{4}$ the process to prepare human beings to live their lives perfectly and happily, love their country, have physical health, behave well, think systematically, have good common sense, work professionally and speak nicely. Another definition, it is the physical and mental guidance based on Islamic laws towards the establishment of noble characteristics. Further, it is asserted that education is the process of instilling virtues gradually and systematically to pupils as the receiver.

It can be summed up that Islamic education ${ }^{5}$ is constituted from three essential dimensions including process, content, and receiver. Besides, there should be something which is instilled gradually in order to acquire self-awareness of the existence of the Divine Being, Allah the Almighty. Thus, education is just given to human beings.

\footnotetext{
${ }^{4}$ Yusuf Qardhawi asserts that Islamic education covers all aspects of human beings including mind and heart, physique and mental, manner and skills. Hence, Islamic education prepares human beings to live peacefully either in war situation or not, to face the community with its virtuousness and wickedness, sweetness and bitterness. (Yusuf Qardhawi, Pendidikan Islam dan Madrasah Hasan al-Banna, translated by H. Bustami A. Ganai and Zainal Abidin Ahmad, Jakarta: Bulan Bintang, 1980, $1^{\text {st }}$ Ed, p. 157).

${ }^{5}$ Islamic education is the process to prepare the young generation to play their role, transfer knowledge and Islamic values adjusted to the function of human beings in the world and harvest the result in the hereafter. (Hasan Langgulung, Beberapa Pemikiran tentang Pendidikan Islam, Bandung: al-Ma'arif, 1980, $1^{\text {st }}$ Ed, p. 94).
} 


\section{b. The Objective of Islamic Education}

Obviously, the purpose of life in Islam becomes the major reference of Islamic education, which is to establish devoted individuals of servants of Allah to live happily in the world and hereafter (QS. alDzariat: 56; and QS. Ali Imran: 102). In sociological context, a devoted individual will be blessing of the world (rahmatan lil 'alamin), either in small or large scale.

According to Abdul Fatah Jalal, the general objective of Islamic education is to materialize humans as the servants of Allah. Education, therefore, should lead humans to serve Allah only which means to worship Him. Through education humans set the purpose of their life as demanded by Allah, that is to serve Him. It is overtly stated in Qur'an Chapter 51, al-Dzariyat: 56. "I have only created Jinns and men, that they may serve Me". Jalal, further, explains that worshipping Allah is not limited only to acting prayers, fasting, paying alms, or performing Hajj pilgrim but it also covers all activities carried out by the name of Allah.

Furthermore, al-Syaibani stresses that the objectives of Islamic education ${ }^{6}$ are as follows.

1) Objectives related to individual. It is dealing with changes in knowledge, behavior, and competencies to gain a happy life in the world and hereafter;

2) Objectives related to society. It is about the behavior of the society, individual behavior in the society, the change of social life, and experience of life in the society;

3) Professional objectives related to education and instruction as science, arts, profession, and social activity.

\footnotetext{
${ }^{6}$ Talking about Islamic education is surely related to the essential purpose of Islamic education itself because the concrete purpose of education will determine its level of attainment. Then, it will become the consideration for educational experts to design a better paradigm of Islamic education theoretically and pragmatically. In the theoretical sense, Islamic education is constituted by the inter-twined Islamic educational theories, whereas the pragmatic sense oversees the implementation of Islamic education, particularly to reach the ultimate goal establishing the perfect humans.
} 
Al-Abrasyi, in addition, mentions that the ultimate objectives of Islamic education include instituting manner, preparing pupils to live well in the world and hereafter, mastering knowledge, and equipping work skills. ${ }^{7}$ Meanwhile, Asma Hasan Fahmi states that the final objectives of Islamic education can be classified into religious objective, mind and manner development objective, cultural learning objective, and character development objective. Munir Mursi adds that the objective of Islamic education is to live happily in the world and hereafter, to serve Allah, to strengthen Islamic bond and actively participate in the Islamic community services, and to be well-behaved.

\section{c. The Foundation and Source of Islamic Education}

The foundation of Islamic education is the Oneness of God (Tauheed). The concept of Tauheed in Islam becomes the fundamental principle for all aspects of lives including education. Experts of Islamic education unanimously decide that the foundation of Islamic education is Tauheed which means there is unity of life, science, faith, religion and characteristics as well as unity of individual and society. Qur'an and Sunnah (prophetic traditions) are believed to be the foundation and also the source of education (QS. Asy-Syuura: 52).

Apparently, Allah the Almighty demands human beings to remind each other about the right path blessed by Allah. Then, in a hadith of Prophet Muhammad PBUH describes a true characteristic of believers ${ }^{8}$ is to keep advising each other in order to actualize the orders of Allah which is manifested into the form of education.

${ }^{7}$ It is further asserted that the Objective of Islamic education is to create perfect humans who own such Qur'anic faces and also to create complete humans. (Abdul Mujib, Ilmu Pendidikan Islam, Jakarta: Fajar Interpratama Offset, 2010, $1^{\text {st }}$ Ed, pp. 84-85).

${ }^{8}$ Believer (in Arabic مؤمن) is a terminology in Islam often mentioned in Qur'an which means a Muslim who can fully obey the orders of Allah and holds a strong faith in his heart. Another opinion says that it does not necessarily mean "someone who believes", but rather someone who is willingly ready to be governed by Islamic rules. Also, it may mean someone who provides comfort to other Muslims. (Wikipedia, Bahasa Indonesia). 
Some principles included in the fundamental of Islamic education are as follows:

1) Education of faith to Allah the Almighty (Q.S. Lukman: 13);

2) Education of noble manner (Q.S. Lukman: 18);

3) Education of worship (Q.S. Lukman: 17);

Furthermore, the source of education, in this case Islamic education, will determine the success of individuals and society in implementing the true Islamic teaching comprehensively. Experts mention some sources of Islamic education, among others Qur'an, Sunnah (prophetic traditions) and Ijtihad prominent Muslim scholars' interpretation and judgment). Moreover, Robert L. Gullick, Jr. in his book "Muhammad the Edu-cator" admits the success of Prophet Muhammad in carrying out education.

\section{d. The Scope of Islamic Education}

The following is the scope of Islamic education. ${ }^{9}$

1) Educating

It is the action to provide guidance or assistance in the class from an Islamic educator in order that the pupils can instill the Islamic mind and soul.

\section{2) Pupil}

Pupils here mean physically, psychologically, socially and spiritually growing individuals. These individuals need someone else to make them mature

\footnotetext{
${ }^{9}$ In one sense especially, Indonesian Islamic higher education is located in Muslim intellectual and pedagogical traditions dating to the mid-nineteenth century when Muslim intellectuals, political and military leaders were confronted with the necessity of responding to what historian Marshall Hodgson (1974) called the "Great western Transmutation." This was the wide-ranging set of scientific, technological, and institutional innovations that, over a period of two centuries (1600-1800), made the industrial revolution, what wallerstein (1974) calls the capitalist world system and western domination possible. Prior to this time there was something of a balance of power between "Christendom" and "Islamdom." western European and Muslim nations and empires had been alternatively seen allies, rivals, enemies, trading partners and interlocutors in intellectual discourse. At the dawn of the twentieth century, most Muslims were subaltern colonial subjects. The few Muslim societies not subject to direct colonial rule were parts of "informal" European empires or capitulation regimes that were less than fully sovereign. The gap between Europe, and the rest of the world in scientific knowledge had expanded at an exponential rate that showed no signs of abating. (Lukens-Bull, 2013: xi-xii).
} 
people. Children are pupils in the family, students are pupils at school, and youngsters are the pupils of the surrounding community.

Likewise, Starawaji states the scope of Islamic education as follows.

1) Educating itself;

It means all activities, actions and attitude by the educator in nurturing the pupils.

2) Pupils;

They are the most important object in Islamic education.

3) Foundation and objective of Islamic education;

It is the fundamental and source of all activities of Islamic education implemented.

4) Educator;

It is the subject of Islamic education

5) Materials of Islamic education;

They are the teaching and learning materials about Islamic sciences.

6) Method of Islamic education;

It is about the way to transfer the Islamic knowledge and skills employed by the educator.

7) Educational Evaluation;

It is dealing with the strategies to assess or evaluate the learning achievement of the pupils.

8) Islamic education tools;

The teaching media and teaching aids needed in the process of teaching and learning in order to facilitate learning achievement.

9) The environment of Islamic education;

It is quite influential towards success in Islamic education. 


\section{National Insight Viewed from Islamic Perspektive}

\section{a. The Understanding of Islamic Education with National Insight}

Islamic education ${ }^{10}$ with national insight substantially is education which leads the Indonesian nation to have such attitude as preserving the unity of Republic of Indonesia to be a prosperous and just country. It can be reached through the total implementation of Islamic education with its three inherent concepts-tarbiyah (education), ta'lim (teaching), and $t a^{\prime} d i b$ (moral learning) which must be simultaneously understood and implemented. These three concepts imply the close relationship between humans and their surroundings and also to their Creator, Allah the Almighty. Besides, they set the scope of Islamic education as informal, formal and non-formal education, too. Hasan Langgulung (1995, in Husna, 2017: 1-2) formulates Islamic education as the process to prepare young generation to play their role, transfer Islamic knowledge and virtues adjusted to the function of human beings to work in the world and to harvest in the hereafter.

Some definitions of Islamic education from different experts are exposed in varied literatures. Firstly, according to Athiyah Al-Abrasy (1972, in Husna, 2017: 2), Islamic education is to prepare human to live happily, love their country, be physically healthy, be well-mannered, have systematic way of thinking, be sensitive to the surroundings, be professional workers, and speak nicely. Then, Ahmad D. Marimba (1980, in Husna, 2017: 2), defines

\footnotetext{
${ }^{10}$ Islamic Education in Indonesia has had a long history in the archipelago. Although unsytematic, it has in its various iterations, served Muslims communities since the early coming of Islam to the area. According to Saefuddin, Islamic education in Indonesia started from a forum of Islamic instructions (pengajian) held by the carrier and preacher of Islam in citizens' houses mosques. The forum was then consolidated into pesantren and madrasah (Saefuddin, 1995: 237). The Pillars of Islamic Education Seen from its stakeholders, at least five pillars of Islamic education in Indonesia can be listed: Pesantren, Madrasah, Islamic schools under Muslim organizations, Islamic Integrated Schools, and Majelis Taklim. Before the twentieth century, pesantren were the only formal institutions of Islamic education in the archipelago, mainly on Java Island (Lukens-Bull, 2004: 299). Pesantren were identified as an Islamic education system whose sole focus was on Islamic curricula. In pesantren santri (students) from various backgrounds studied Islamic values and teachings from the Kyai (teacher). Like the pesantren, madrasah were also know for their core focus on center for the instruction of Islamic teaching and Arabic language. But unlike the pesantren, where the Kyai is the one who has the authority to teach students and determine the curricula, madrasah were usually managed by a group of Muslims, and one who delivered Islamic teaching, called guru or Ustadz. "Secular sciences" such as natural sciences, math, and other social and humanistic sciences were not taught in Indonesia until the Dutch government introduced school on the basis of the "Western educational system." (Abdullah, 2010).
} 
Islamic education as physical and mental guidance based on Islamic laws to achieve Islamic charac-teristics. Syed Muhammad Naquib Al-Attas (in Husna, 2017: 2), ${ }^{11}$ asserts that education is the process of gradually instilling a certain value into human with a certain method.

Besides, the history of incorporating the national insight into Islamic education has gone through a dynamic and complex process. It eventually arrives at an ideological synthesis of typical Indonesian nation-religious nationalism. It is derived from the synthesis of nationalism which is neutral from any religious interest and that of Islam. Another influential factor is the wisdom of national tradition and socialism-communism. The concoction of these elements produces a kind of nationalism concept which is different from that in the origin of nationalism, Western Europe and the United States, even other places. Another thing which justifies the concept of religious nationalism ${ }^{12}$ is the empirical reality of the characteristics of the formulators of Pancasila, especially the members of the Nine Committee comprising the representatives of Islam and those of nationalists who were notably Muslims, except A.A. Maramis. It is surely unfair to claim that the nationalists were truly secularist, neutral of religious interest and put aside the religious values

Furthermore, Islamic education with national insight becomes the very influential factor to develop this nation. It is urgent to actualize it since up to now Indonesian Muslim community is left behind in the field of education. Accordingly, it is a high time to revitalize the implementation of Islamic education which is particularly aimed at developing Muslim lives in

${ }^{11}$ If we observe further, the existence of Islamic education substantially is talking about the status of its power in the system. The position of Islamic education in the context of national education system, in this case is very significant. It has something to do with the arrangement of national education system itself and the nature of education in the religious lives of Muslims in Indonesia. Islamic education in Indonesia historically has been lasting and growing since the introduction of Islam in Indonesia. Firstly it was in the form of informal education through the preaching of Islam. (Fauziyatul Halim, et.al., Op.Cit., h. 7).

${ }^{12}$ Nowadays, religious nationalism is the national concept and characteristic the most suitable and relevant to Indonesia with its plural society. Pancasila is becoming the culmination point of the plurality of ethnicity, religion and culture manifested as the ideology and foundation of the state. The 1945 Constitution is the integral part of Pancasila. Upon such state philosophy, any follower of any religion and any member of any ethnic group can play their role in developing the nation. (Anhar, Nasionalisme Religius: Identitas Wawasan Kebangsaan Umat Islam Indonesia, Scientific Article, p 16. Accessed on Saturday, January, 14, 2017.). 
Indonesia. On one side, Indonesian government is very concerned about the development of Islamic education with national insight. On the other side, there is inequality of development of general educational institution and Islamic educational institution.

\section{b. The Nature of Islamic Education with National Insight}

It is the national concept and characteristic which is undoubtedly relevant to the context of Indonesia with the plural society. ${ }^{13}$ Moreover, Islamic education with national insight based on the perspective of Qur'an and Hadith is becoming actual issue to discuss intensely regarding the effort to preserve the unity of Republic of Indonesia. Pancasila is becoming the culmination point of the plurality of ethnicity, religion and culture manifested as the ideology and foundation of the state. The 1945 Constitution is the integral part of Pancasila. Upon such state philosophy, any follower of any religion and any member of any ethnic group can play their role in developing the nation. As the biggest population in this country, Muslims in Indonesia have the great chance to struggle wholeheartedly to implement Pancasila with the Islamic values by implying the religious values suitable with the interpretation and implementation of 1945 Constitution. This way, Indonesian Muslims will be ethical and civilized Muslims, not in formal or symbolic perspective like the expectation in the past to institute the Islamic State.

In addition, Islam as the religion with the most followers in Indonesia when involved in shaping the ideology during the reformation era will, of course, draw people's attention.

\footnotetext{
${ }^{13}$ A plural society is defined by Fredrik Barth as a society combining ethnic contrasts: the economic interdependence of those groups, and their ecological specialization (i.e., use of different environmental resources by each ethnic group). The ecological interdependence, or the lack of competition, between ethnic groups may be based on the different activities in the same region or on long-term occupation of different regions in the Defined by J S Furnivall as a medley of peoples - European, Chinese, Indian and native, who do mix but do not combine. Each group holds by its own religion, its own culture and language, its own ideas and ways. As individuals they meet, but only in the marketplace in buying and selling. There is a plural society, with different sections of the community living side by side, within the same political unit. (From Wikipedia, the free encyclopedia).
} 
According to As'ad Said Ali (2012: 549), Islamism as a political ideology in the reformation era can be classified into four notions: modernist Islam, traditionalist-conservative Islam, Islam transformism, and Fundamentalist Islam. Of the four groups above, we still can find some variants that wish to put all Muslims in the world under the one caliphate. They are trying to change the concept of the unity of Republic of Indonesia to be a religious state, change the state ideology of Pancasila to be their version of Islamic ideology, and eliminate the existence of Republic of Indonesia to be merged into the Islamic caliphate (As'ad Said Ali, 2012: 64). Hence the presence of Islamic education with national insight is absolutely needed because through the systematic and well planned educational process in order to prepare the readyfor-use young generation who are ready to face the great ever changing challenges the unity of this nation can be preserved successfully. It is surely in line with the overt statement in Qur'an describing the process of physical, mental and behavioral growth and development as asserted in Qur'an chapter As-Syu' ara verse 18 and Al-Israa' verse 24.

\section{c. Islamic Education with National Insight Viewed from Islamic Perspective}

About this concept, it can be discerned from some remarkable works of some Muslim scholars that they have distinctive and typical characteristics of thoughts. In this context, at least there are three Muslim scholars who have contributed positively upon the development the issue. They are Muhammad Abduh, al-Ghazali and Azra. Abduh's thought is related to the establishment of noble characteristics through education and instilling the moral values to be good people, and it can only be achieved through educational process. Further, Abduh asserts that education is a medium of change and the true education is the one that is in accordance with Islamic teachings. Next, the specification of Islamic education is to attain religious behavior, but without ignoring the worldly targets. Al-Ghazali himself as the prominent figure of Sufi did not ignore the worldly matters which could be addressed through education. Education is a noble activity, and it is the medium to be close to Allah the Almighty. It can also be the cause of getting happiness in the world and 
hereafter if it is carried out in a proper balance. It is aimed at acquiring the decent knowledge even though it is not an easy process to make the knowledge received useful for the pupils themselves and other people. Educational sector according to al-Ghazali-both the objective and the way to achieve it-can be carried out in the religious environment for instance Islamic boarding school and Islamic school. At this time, this educational system is running in Indonesia. Moreover, many children are studying at Islamic boarding school, ${ }^{14}$ so they can learn about general knowledge at school and the religious lessons at the boarding school.

While Azra (2015: 59) explained that Indonesian experience of the reform of Islamic education ${ }^{15}$ highlights three main implications for policy makers, educators and practitioners. The first implication is the benefit of offering different types of Islamic educational institutions, be they pesantrens, madrasas or sekolah Islams, to cater to different needs of Muslims in society. Secondly, Islamic educational institutions need to integrate religious and secular education, as well as offer a curriculum that balances religious concerns with the challenges of modernization. Finally, it is imperative for Islamic education leaders to be open-minded to diversity and innovations within and outside the Islamic faith, constantly progressing to ensure that their institutions remain socioculturally relevant. It means that it refers to the principles actualized by

\footnotetext{
${ }^{14}$ Islamic boarding school is a kind of traditional educational institution where the students live together at a boarding house and study under the guidance of a teacher commonly called kiyai. In the compound there are also some other facilities including mosque, classrooms, and some other buildings. This compound is usually surrounded by fence to control the students' in-and-out activity referring to the existing rules and regulations.(Zamakhsyari Dhofier, 1983: 18).

${ }^{15}$ The reform of Islamic education is a hotly contested issue among Muslim societies since the time of introduction of Islamic reforms, renewal and modernization, in the late nineteenth-and early twentieth centuries. Muslims have been polarized in their responses to the idea of reforms in Islamic education. There are those who oppose the reforms, believing that Islamic education is the most important medium for the inculcation of Islamic teaching in Muslim youth, and that reforms in Islamic education will lead not only to modernization, but also the 'secularization' of Muslim societies. On the other hand, those who support the reforms believe that they are necessary in order for Muslims to be able to cope with the modern world. Therefore, even till today, reforms in Islamic education remain an unfulfi lled agenda. Only a few Muslim countries have successfully conducted reforms. This chapter discusses the reform of Islamic education in Indonesia and demonstrates that such reform is infl uenced by a combination of social, cultural and political factors that make reforms both necessary and possible, (Azyumardi Azra, 2015: 59).
} 
the Prophets of Allah. As a modernist-theologian, Abduh is convinced that there is no contradiction between science and Islam. Both work at different level of discourse. He, then, offered the development prospective by maintaining the continuity of the past events.

The previous description of Islamic education national insight viewed from Islamic perspective draws attention to the understanding that Islamic education with national insight is the way of life of Indonesian people - multi-ethnicity, plurality of religions and cultures - in preserving the unity of Republic of Indonesia to be a just and prosperous country. Further, the nature of Islamic education with national insight is an Islamic-based concept of thought originated from the noble values of Qur'an and Hadith which are transformed into the systematic and wellplanned educational process to meet the challenges of the ever changing era. Meanwhile, Islamic education with national insight viewed from Islamic perspective can be discerned from the ideas proposed by two prominent Muslim scholars including Muhammad Abduh and al-Ghazali which they all agreed that substantially this sort of education is aimed at generating perfect humans based on Qur'an and Sunnah.

\section{Conclusion}

It can be summed up that the view of Islam on Islamic education with national insight is education that leads to the way of life of Indonesian people multi-ethnicity, plurality of religions and cultures - in preserving the unity of Republic of Indonesia to be a just and prosperous country.

Further, the nature of Islamic education with national insight is an Islamic-based concept of thought originated from the noble values of Qur'an and Hadith which are transformed into the systematic and well-planned educational process to meet the challenges of the ever changing era.

The implementation of Islamic education with national insight in Indonesia is the educational activities with the intention to actualize the Islamic teachings and values. The stages of implementation can be categorized into four dimensions, namely: religious education (Islamic boarding school, Islamic school/ madrasah, and Islamic higher 
educational institution); Islamic pre-school; non-formal education; and informal education like the Islamic education carried out in the family, at the worship places, and others.

\section{E. Recommendation}

Considering the findings of this research, the following points are necessarily recommended.

1. To Indonesian Government

Indonesian government should be more intense to socialize and assist the development of Islamic education with national insight in order to keep the unity of Republic of Indonesia.

\section{To Islamic Higher Educational Institutions}

All faculty members of the Islamic higher educational institutions should be aware of the threat of radicalism and liberalism doctrine which may ruin the unity of the nation and by implementing Islamic education with national insight the students and alumni will not be part of people who deviate from the Islamic true teachings due to partial comprehension of Islamic virtues. Otherwise, it will just degrade the reputation of the institution and lead to the negative image in the society.

3. To the Researcher

The teacher should be conscientious in comprehending the concept of Islamic education with national insight viewed from Islamic perspective in order that he can provide proper alternative solutions to Indonesian people in keeping the unity of the Republic of Indonesia.

\section{Bibliography}

A., Ronald, Lukens-Bull, (2013), Islamic Higher Education in Indonesia: Continuity and Conflict, India: Palgrave Macmillan.

Abduh, Muhammad, (1966), The Theology Of Unity, translated by Ishaq Musaad dan Kenneth Cargy, London: George Allen and Unwin. 
Abdul Majid Khon, (2012), Hadis Tarbawi: Hadis-Hadits Pedidikan, Jakarta: Kencana Prenada Media Group.

Abdullah Nashih ‘Ulwan, (1997), Tarbiyah al-Aulad Fi al-Islam, al-Qahirah: Dar al-Salam.

Abdullah, A.M. (2010), Religious Diversity And Islamic Education In IndonesiaScientific Article-Accessed on Monday, December, 26, 2017.

al-Abrasy, 'Athyah, Muhammad, (1970), Dasar-Dasar Pokok Pendidikan Islam, Jakarta: Bulan Bintang.

al-Baidhawi, (2000) Anwar al-Tanzil wa Asrar al-Ta'wil Fi Ushul al-Tarbiyah al-Islamiyah, Munawwarah: Dar 'Alam al-Kutub.

al-Hazimi, Ibn Hamid, Khalid, (2000), Ushul al-Tarbiyah al-Islamiyah, alMadinah al-Munawwarah: Dar 'Alam al-Kutub.

Ali, A.S. (2012), Gerakan-Gerakan Sosial-Politik dalam Tinjauan Ideologis; Ideologi Gerakan Pasca-Reformasi-Kata Pengantar, Jakarta: LP3ES.

al-Raghib al-Ishfahani, al-Mufradat Fi Gharib al-Qur'an, Beirut: Dar al-Fikr, Year Untraced.

al-Tarbiyah Fi al-Islam, (1975), Mishr: Dar al-Ma'arif. fi Abi Lubabah Husein, al-Tarbiyah Fi al-Sunnah al-Nabawiyah, al-Riyadh: Dar al$\mathrm{Lu}^{\prime}-\mathrm{lu}$ ', Year Untraced.

Anhar, Nasionalisme Religius: Identitas Wawasan Kebangsaan Umat Islam Indonesia-Scientific Article-Accessed on Saturday, January, 14, 2017.

Azra, A, Revitalisasi Pendidikan Agama, Gatra, 30 September 2009.

Departemen Pendidikan dan Kebudayaan, (1998), Direktorat Jenderal Pendidikan Dasar dan Menengah ,Bagian Proyek Peningkatan Wawasan Kepen-didikan Guru Agama, Bahan Dasar Peningkatan Keagamaan (Islam) Guru Bukan Pendidikan Agama dan SLTA, Jakarta: Depdikbud.

Departemen Pendidikan Nasional, (2012), Kamus Besar Bahasa IndonesiaPusat Ba-hasa-Jakarta: PT. Gramedia Pustaka Utama.

Dhofier, Z, (1983), Tradisi Pesantren Studi tentang Pandangan Hidup Kyai, Jakarta: LP3S.

Elson, E., R., (2009), The Idea of Indonesia; Sejarah Pemikiran dan Gagasan, Jakarta: Serambi Ilmu Semesta.

Halim, Fauziyatul, et.al., (2014), Pandangan Pendidikan dalam Ditinjau dari Per-spektif Islam-Scientific Article-Under supervisory of Dr. Imam 
Jau-hari, SH., M. Hum. Universitas Syiah Kuala Program Pascasarjana Ilmu Hukum Darussalam Banda Aceh. Accessed on Saturday, 14 January 2017.

Hasan, A. Pengertian, Dasar dan Tujuan Pendidikan Islam-First Scientific Article, Accessed on Saturday, January, 14, 2017.

Hitami, M, (2004), Menggagas Kembali Pendidikan Islam, Yogyakarta: Infinite Press.

Husein, Lubabah, Abu, al-Tarbiyah Fi al-Sunnah al-Nabawiyah, al-Riyadh: Dar al-Lu'lu', Year Untraced.

Idris, S \& Tabrani, Z. A. (2017). Realitas Konsep Pendidikan Humanisme dalam Konteks Pendidikan Islam. Jurnal Edukasi: Jurnal Bimbingan Konseling, 3(1), 96-113.

Idris, S \& Tabrani, Z. A. (2017). Realitas Konsep Pendidikan Humanisme dalam Konteks Pendidikan Islam. Jurnal Edukasi: Jurnal Bimbingan Konseling, 3(1), 96-113.

Konsep Pendidikan dalam Perspektif Muhammad Abduh-Scientific ArticleAccessed on Saturday, January, 14, 2017.

Konsep Pendidikan Menurut Pandangan Tokoh Islam-Scientific ArticleAccessed on Saturday, January, 14, 2017.

Langgulung, H. (1980), Beberapa Pemikiran tentang Pendidikan Islam, Bandung: al-Ma'arif.

Langgulung, H. (1995), Manusia dan Pendidikan Suatu Analisa Psikologidan Pendidikan, Jakarta: PT. al- Husna Zikra.

Madjid, N. (1997), Bilik-Bilik Pesantren Sebuah Potret Perjalanan, Jakarta: Paramadina.

Madjid, N. (1998), Dialog Keterbukaan: Artikulasi Nilai Islam dalam Waca-na Sosial Politik Kontemporer, Jakarta: Paramadina.

Marimba, A.D. (1980), Pengantar Filsafat Pendidikan Islam, Bandung: al-Ma'arif.

Mujib, A. (2010), Ilmu pendidikan Islam, Jakarta: Fajar Interpratama Offset.

Muslih Usa, et.al., (1991), Pendidikan Islam di Indonesia: Antara Cita dan Fakta, Yogyakarta: TiaraWacana.

Nasution, S.M. (2017) Pemikiran Pendidikan Islam Murtadha MuthahhariScientific Article-Accessed on Saturday, 14 January 2017. 
Qardhawi, Y. (1980), Pendidikan Islam dan Madrasah Hasan al-Banna, translated by H. Bustami A. Ganai dan Zainal Abidin Ahmad, Jakarta: Bulan Bintang.

Saefudin, D. (2003), Pemikiran Modern dan Post Modern Islam, Jakarta: Grasindo.

Sanaky, H.A.H. (2003), Paradigma Pendidikan Islam: Membangun Masyarakat Madani Indonesia, Yogyakarta: Safiria Insania Press.

Sutrisno. (2011), Pembaharuan dan Pengembangan Pendidikan Islam: Membentuk Insan Kamil yang Sukses dan Berkualitas, Yokyakarta: Fadilatama.

Syalabi, A. (1945), Tarikh al-Tarbiyah al-Islamiyat, Kairo: al-Kasyaf.

Tabrani. ZA \& Masbur, M. (2016). Islamic Perspectives on the Existence of Soul and Its Influence in Human Learning (A Philosophical Analysis of the Classical and Modern Learning Theories). Jurnal Edukasi: Jurnal Bimbingan Konseling, 1(2), 99-112.

Tabrani. ZA \& Masbur, M. (2016). Islamic Perspectives on the Existence of Soul and Its Influence in Human Learning (A Philosophical Analysis of the Classical and Modern Learning Theories). Jurnal Edukasi: Jurnal Bimbingan Konseling, 1(2), 99-112.

Tabrani. ZA. (2014). Islamic Studies dalam Pendekatan Multidisipliner (Suatu Kajian Gradual Menuju Paradigma Global). Jurnal Ilmiah Peuradeun, 2(2), 211-234.

Tabrani. ZA. (2014). Isu-Isu Kritis dalam Pendidikan Islam. Jurnal Ilmiah Islam Futura, 13(2), 250-270

Tabrani. ZA. (2016). Perubahan Ideologi Keislaman Turki (Analisis GeoKultur Islam dan Politik Pada Kerajaan Turki Usmani). Jurnal Edukasi: Jurnal Bimbingan Konseling, 2(2), 130-146.

Tan, C. (2015), Reforms in Islamic Education: International Perspective, London: Bloomsbury.

Tan, C. (2015). Educative Tradition and Islamic School in Indonesia. Jurnal Ilmiah Peuradeun, 3(3), 417-430.

Tim Redaksi New Merah Putih, (2009), Amandemen Undang-Undang Dasar 1945, Yogyakarta: Penerbit New Merah Putih.

Unknown, Wawasan Kebangsaan Islam dan Pancasila- Scientific Article, Accessed on Saturday, January, 14, 2017.

Voll, J.O. (1982), Islam Continuity and Change in the Modern World, NewYork: Westview Press. 